\title{
PERBEDAAN PROKRASTINASI AKADEMIK DALAM MENYELESAIKAN SKRIPSI PADA MAHASISWA FAKULTAS PSIKOLOGI UKSW BERDASARKAN TIPE KEPRIBADIAN A DAN B
}

\author{
Sutriyono, Riyani, dan Berta E. A. Prasetya \\ Fakultas Psikologi Universitas Kristen Satya Wacana
}

\begin{abstract}
ABSTRAK
Jenis penelitian ini adalah penelitian komparasi yang bertujuan untuk mengetahui perbedaan tingkat prokrastinasi akademik dalam menyelesaikan skripsi pada mahasiswa Fakultas Psikologi Universitas Kristen Satya Wacana (UKSW) ditinjau dari kepribadian tipe A dan tipe B. Sebanyak 63 mahasiswa semester genap 2011/2012 yang mengambil matakuliah skripsi dan skripsi lanjut dilibatkan. Alat pengumpul data menggunakan dua skala, yang pertama adalah modifikasi skala prokrastinasi Tuckman (Tuckman Procrastination Scale) untuk mengukur tingkat prokrastinasi dan modifikasi skala Bortner untuk menggolongkan kedalam salah tipe kepribadian. Hasil penelitian menunjukkan bahwa secara signifikan, mahasiswa dengan kepribadian tipe A mempunyai tingkat prokastinasi dalam menyelesaikan skripsi lebih rendah dibandingkan dengan mahasiswa yang mempunyai tipe kepribadian B.
\end{abstract}

Kata Kunci: prokrastinasi akademik, skripsi, tipe kepribadian

\section{PENDAHULUAN}

Terkait masalah lamanya mahasiswa dalam menjalani proses pembelajaran di perguruan tinggi, Semb, Dlick, \& Spencer (dalam Solomon \& Rothblum, 1984, h. 503) dalam penelitiannya menyatakan bahwa semakin lama mahasiswa menjalani kuliah di Perguruan Tinggi semakin tinggi tingkat prokrastinasinya. Fenomena prokastinasi ini juga terjadi di Fakultas psikologi Universitas Kristen Satya Wacana (UKSW) Salatiga. Dari tahun 2001 s/d tahun 2007 terjadi fluktuasi kelambatan mahasiswa dalam menyelesaikan studi dari yang seharusnya, maka terjadilah apa yang disebut dengan bottleneck. Tahun 2001 s/d 2003 bottleneck menurun dari 67 persen menjadi 35 persen, kemudian naik lagi hingga 82 persen pada tahun 2007. Banyak faktor penyebab mahasiswa tidak dapat menyelesaikan studinya dengan tepat waktu. Faktor penyebab berasal dari diri mahasiswa dan di luar mahasiswa itu sendiri. Dalam konteks penelitian ini yang dilihat adalah lebih kepada faktor yang berasal dari dalam diri individu mahasiswa itu sendiri, yang dalam hal ini adalah kepribadian dan prokrastinasi.

Untuk dapat menyelesaikan studi di perguruan tinggi salah satu persyaratan yang wajib bagi seorang mahasiswa adalah membuat karya ilmiah berupa skripsi. Bagi sebagian mahasiswa menyusun skripsi sering merupakan hal yang menakutkan. Lutfin (dalam Catrunada \& Puspitawati, 2008, h.4) memaparkan bahwa ketidakmampuan mahasiswa menulis skripsi berkaitan dengan berbagai hal antara lain, masalah penguasaan teknik penulisan, penguasaan bahasa, kurangnya membaca, kurangnya sumber bacaan, dan kebiasaan menulis. Kesulitan lain yang seringkali dialami di antaranya juga kesulitan mencari permasalahan, kesulitan mencari literatur atau bahan bacaan, dana yang terbatas, atau takut menemui dosen pembimbing dan sebagainya. Bagi banyak mahasiswa yang merasa tidak berdaya menghadapi hambatan tersebut, akhirnya berusaha untuk menghindar atau mengulur-ulur waktu untuk menyelesaikan skripsi tersebut. Dalam hal ini mahasiswa tersebut melakukan prokrastinasi akademik yang tentu saja dengan berbagai alasan (Gunawinata, Nanik, \& Lasmono, 2008, h. 256). 
Di samping beberapa hal yang menjadi penghambat mahasiswa melakukan prokastinasi juga tidak dapat dilepaskan dari kepribadian mahasiswa sendiri (Bernard dalam Catrunada \& Puspitawati, 2008, h. 4). Hal tersebut didukung oleh penelitian Díaz-Moralez, Cohen, \& Ferrari (2008) yang menyatakan bahwa prokrastinasi sebagai suatu kebiasaan kepribadian, dalam pengertian ini prokrastinasi tidak hanya sebuah perilaku penundaan akan tetapi prokrastinasi merupakan suatu kebiasaan yang melibatkan komponen-komponen perilaku maupun struktur mental lainnya yang saling terkait yang dapat diketahui secara langsung maupun tidak langsung. Kepribadian sebagai faktor yang memegang peranan penting dalam perilaku sehari-hari dan merupakan suatu bagian yang tidak terpisahkan dalam lingkungan di mana individu tinggal. Hal ini sejalan dengan Chu \& Choi (2005) yang menyarankan kepada peneliti selanjutnya untuk mengangkat variabel kepribadian khususnya kepribadian tipe A dan tipe B terhadap kecenderungan prokrastinasi.

Pada tahun 1988, studi yang dilakukan oleh Milgram, Sroloff, \& Rosenbaum mengenai regulasi diri, pola perilaku kepribadian tipe A, dan kepuasan hidup dengan prokrastinasi pada 314 mahasiswa Universitas Tel Aviv menunjukkan bahwa prokrastinasi berhubungan negatif dengan pola perilaku kepribadian tipe A ( $r=-0.57$ untuk karakteristik competitiveness dan $r=-0.31$ untuk karakteristik time urgency). Milgram, Sroloff, \& Rosenbaum (1988) juga menegaskan bahwa hal tesebut disebabkan oleh adanya kecenderungan individu berkepribadian tipe A yang suka mengerjakan sesuatu dengan cepat sehingga tugas-tugasnya dapat terselesaikan dengan segera tanpa perlu menundanya. Rasa kompetitif yang tinggi dan usaha yang keras (hard-driving) untuk mendapatkan suatu penghargaan juga memaksa individu berkepribadian tipe A untuk mengerjakan tugasnya lebih baik dan lebih cepat dari orang lain meskipun beberapa tugas tidak disukainya.

Sebaliknya, semakin rendah kecenderungan pola perilaku kepribadian tipe A atau yang disebut dengan pola perilaku kepribadian tipe B semakin tinggi prokrastinasinya. Hal tersebut disebabkan pola perilaku kepribadian tipe B yang cenderung santai dalam hal waktu, tidak menyukai kesukaran serta tidak berorientasi pada penghargaan sehingga membuat individu tersebut menghindarkan diri pada tugas-tugas yang menyulitkannya atau tidak disukainya dan melakukan suatu tindakan penundaan. Milgram, Sroloff, \& Rosenbaum (1988) menyatakan bahwa prokrastinasi tidak berkaitan dengan ciri individu kepribadian tipe A. Hal tersebut diperkuat oleh studi yang dilakukan Watson (dalam Díaz-Moralez, Cohen, \& Ferrari, 2008) yang menjelaskan bahwa prokrastinasi memang berkaitan dengan ciri individu kepribadian tipe B. Hal ini berbeda dengan temuan Aristia (2010) yang meneliti 99 siswa SMA Regina Pacis Ursulin Solo yang mendapatkan hasil bahwa tidak ada perbedaan tingkat prokrastinasi akademik antara siswa dengan kepribadian tipe A dan tipe B.

Berdasarkan latar belakang tersebut di atas dirumuskan masalah penelitian sebagai berikut: Adakah perbedaan tingkat prokastinasi akademik dalam menyelesaikan skripsi diantara mahasiswa Psikologi UKSW yang bertipe kepribadian A dengan mahasiswa yang bertipe kepribadian B.

Selanjutnya tujuan dari penelitian ini adalah untuk mengetahui signifikansi perbedaan tingkat prokastinasi akademik dalam menyelesaikan skripsi diantara mahasiswa Psikologi UKSW yang bertipe kepribadian A dengan mahasiswa yang bertipe kepribadian B.

\section{TINJAUAN PUSTAKA}

\section{Prokrastinasi Akademik}

Kata prokrastinasi sebagaimana dikemukakan oleh DeSimone (dalam Ferrari, Johnson, \& McCown, 1995) berasal bahasa Latin procrastinare yang secara semantik terdiri dari dua kata yaitu pro dan cratinus. Istilah pro berarti "bergerak ke depan (moving forward)" sedangkan cratinus 
berarti "milik hari esok (belonging to tomorrow)". Sehingga istilah procrastinare mempunyai makna "menunda sampai kepada hari berikutnya". Tuckman (1990, h. 4) menjelaskan bahwa prokrastinasi termasuk dalam permasalahan regulasi diri yaitu merupakan kecenderungan untuk menangguhkan atau menghindari aktivitas atau tugas yang harus diselesaikan. Menurut Schou-weburg, Lay, Phycyl, \& Ferrari (dalam Díaz-Moralez, Cohen \& Ferrari 2008, h. 554) prokrastinasi merupakan penundaan terhadap hal yang diperlukan untuk mencapai suatu tujuan.

Prokrastinasi bisa dilakukan oleh siapa saja dan di mana saja. Burka \& Yuen (dalam Ferrari \& Tice, 2000) mengemukakan bahwa prokrastinasi bisa dilakukan pada berbagai macam tugas dan dalam berbagai konteks. Ely \& Hampton, Hill et.al dan Rosati sebagaimana dinyatakan dalam Milgram, Sroloff, \& Rosenbaum (1988) mengemukakan bahwa prokrastinasi merupakan suatu fenomena terkenal yang yang banyak diteliti dalam dua wilayah diantaranya prokrastinasi akademik dan non-akademik. Wilayah yang pertama yaitu prokrastinasi akademik mengacu pada penundaan secara sengaja dalam menyelesaikan tugas-tugas dalam lingkup kehidupan akademik. Secara lebih terperinci, Solomon \& Rothblum (1984) memberikan beberapa jenis tugas yang diprokrastinasi oleh pelajar atau mahasiswa dalam lingkup akademis. Ruang lingkup kehidupan akademis tersebut dapat meliputi berbagai tugas seperti menulis makalah (writing a term paper), belajar untuk menghadapi ujian (studying for exams), membaca (reading assignments), administratif seperti mencatat dan meringkas materi (administrative tasks), kehadiran dalam pertemuan kelas (attendance tasks) dan aktivitas-aktivitas sekolah lainnya secara umum (activities in general). Sedangkan wilayah yang kedua yaitu non-akademik mengacu pada penundaan yang dilakukan dalam membuat suatu keputusan dalam permasalahan kehidupan lainnya seperti halnya dalam lingkup pekerjaan, sosial. rumah tangga, mencari pasangan hidup dan lain sebagainya.

Berdasarkan uraian di atas, bisa disimpulkan bahwa prokrastinasi akademik merupakan tindakan penundaan yang dilakukan secara sengaja terhadap tugas-tugas dalam lingkup kehidupan akademik yang berguna untuk mencapai suatu tujuan tertentu.

\section{Aspek Prokrastinasi}

Menurut Tuckman (1990) terdapat 3 aspek prokrastinasi yaitu: (1) Tendency to delay or put off doing things/pembuang waktu. Ini merupakan kecenderungan untuk membuang waktu secara sia-sia dalam menyelesaikan tugas yang perlu diprioritaskan demi melakukan hal-hal lain yang kurang penting. (2) Tendency to have difficulty doing unpleasant things and when possible to avoid or circumvent the unpleasantness/kesulitan dan penghindaran dalam melakukan sesuatu yang tidak disukai. Ini merupakan kecenderungan untuk merasa berkeberatan mengerjakan hal-hal yang tidak disukai dalam tugas yang harus dikerjakannya tersebut atau jika memungkinkan akan menghindari hal-hal yang dianggap mendatangkan perasaan tidak menyenangkan. (3) Tendency to blame others for one's own plight/menyalahkan orang lain. Merupakan kecenderungan untuk menyalahkan pihak lain atas penderitaan yang dialami diri sendiri dalam mengerjakan sesuatu yang ditundanya.

\section{Faktor-Faktor Prokrastinasi}

Menurut Burka \& Yuen (2008) faktor-faktor yang mempengaruhi prokrastinasi dapat berasal dari luar diri individu (eksternal), dan juga berasal dari dalam diri individu (internal). Faktor eksternal meliputi (1) pemberontakan terhadap kontrol dari figur otoritas. (2) pengalaman dalam suatu kelompok. (3) model-model sukses maupun kegagalan. Faktor internal meliputi (1) fear of failure atau adanya ketakutan terhadap kemungkinan terjadinya kegagalan. (2) fear of success atau adanya ketakutan akan akibat yang mungkin didapat dari keberhasilan yang dicapai. (3) fear of losing the 
battle atau adanya ketakutan akan kehilangan kontrol terhadap dirinya. (4) fear of attachment atau adanya ketakutan akan menjadi terkungkung, terbatasi apabila individu membiarkan orang lain menjalin hubungan yang dekat dengannya. (5) fear of separation adalah pada saat seorang individu merasa ketakutan akan menjadi sendirian.

Sedangkan Bernard (dalam Catrunada \& Puspitawati, 2008) mengungkapkan sepuluh wilayah magnetis yang menjadi faktor-faktor dilakukannya prokrastinasi. Kesepuluh faktor tersebut adalah: (1) kecemasan (Anxiety), (2) pencelaan terhadap diri sendiri (self-depreciation) atau pencelaan terhadap diri sendiri, (3) rendahnya toleransi terhadap ketidaknyamanan (low discomfort tolerance), (4) pencarian kesenangan atau kenyamanan (pleasure-seeking), (5) kurang dalam pengaturan waktu (time disorganization), (6) lingkungan yang kurang teratur dan mendukung (environmental disorganization), (7) pendekatan yang lemah terhadap tugas (poor task approach), (8) kurang mampu memberikan ketegasan (lack of assertion), (9) permusuhan dengan orang lain (hostility with others), (10) kondisi tertekan dan kelelahan (stress and fatigue).

\section{Kepribadian}

Kepribadian merupakan salah satu faktor yang dapat menimbulkan perbedaan individu dan seringkali dirumuskan berbeda oleh banyak ahli. Sebagaimana dikutip dalam Sobur (2003, h. 300), G.W Allport mengemukakan bahwa tidak kurang dari lima puluh definisi kepribadian dari para ahli yang berbeda-beda dan jumlahnya kian bertambah banyak. Allport sendiri berpendapat bahwa personality is the dynamic organization within the individual of those psychophysical system, that determines his unique adjustment to his environtment, artinya kepribadian adalah suatu organisasi dinamis dari sistem-sistem psikofisis dalam individu yang turut menentukan cara-caranya yang unik (khas) dalam menyesuaikan diri dengan lingkungannya. Dengan kata lain dapat dinyatakan bahwa kepribadian merupakan totalitas psikofisis yang kompleks yang dapat menjadikan individu itu unik dalam lingkungannya.

\section{Kepribadian Tipe A dan Tipe B}

Rumusan yang dikemukakan oleh Bortner (dalam Edwards, Baglioni, \& Cooper, 1990) mengenai kepribadian tipe A dan tipe B menjelaskan bahwa ciri yang dapat dilihat dari tipe A adalah individu yang mengerjakan tugas dengan cepat, mempunyai sikap kompetitif yang tinggi, berusaha mati-matian untuk mencapai hasil yang lebih baik, tidak sabar dengan cara apapun untuk mencapai tujuan yang diinginkannya atau menyelesaikan tugas kurang dari waktu yang ditentukan, berorientasi pada prestasi, ambisius, agresif, tergesa-gesa. Secara umum kepribadian tipe A dirumuskan menjadi 3 kesimpulan sebagaimana dikutip dalam Edwards, Baglioni, \& Cooper (1990, h. 315) yaitu cenderung kompetitif dalam kebutuhannya untuk mencapai penghargaan (competitive need for achievement), merasa diburu oleh waktu (sense of time urgency) serta kecenderungan agresif dan rasa permusuhan (aggressive and hostility).

Lawan dari tipe tersebut adalah kepribadian tipe B yang mempunyai ciri-ciri rileks, tidak suka kesulitan, jarang marah, menggunakan banyak waktunya untuk kegiatan yang disenangi, tidak mudah stres, tidak mudah iri, jarang kekurangan waktu dan berbicara dengan nada suara pelan dan bergeraknya lamban. Dari perbedaan karakteristik tersebut, menunjukkan bahwa individu dengan kepribadian tipe A cenderung mengalami stres yang lebih tinggi yang berhubungan dengan sakit jantung koroner, dibandingkan dengan individu yang mempunyai kepribadian tipe B (Friedman \& Rosenman, 1974). 


\section{Prokrastinasi dan Kepribadian Tipe A \& B}

Waldron, Zyzanski, Shekelle, Jenkins \& Tanenbaum sebagaimana dicatat dalam Milgram, Sroloff \& Rosenbaum (1988) mengemukakan bahwa pola perilaku kepribadian tipe A mempunyai satu karakteristik yang umum dengan prokrastinasi yaitu dalam hal orientasi terhadap tekanan waktu dan usaha yang diberikan dalam melakukan aktivitas tertentu. Meski berada dalam satu karakteristik, namun individu berkepribadian tipe A mempunyai perilaku yang berkebalikan dengan seorang prokastinator $\mathrm{B}$, dimana individu berkepribadian tipe A menyadari adanya tekanan dalam hal waktu sehingga berusaha mengerjakan hal-hal dengan cepat sementara seorang prokrastinator B masih tetap duduk diam meski ia menyadari adanya tekanan dalam hal waktu.

Hal tersebut juga didukung oleh studi yang dilakukan oleh Milgram, Sroloff, \& Rosenbaum (1988) pada 314 mahasiswa Universitas Tel-Aviv yang mendapatkan bahwa prokrastinasi berhubungan negatif dengan pola perilaku kepribadian tipe A ( $r=-0.57$ untuk karakteristik competitiveness dan $r=-0.31$ untuk karakteristik time urgency). Milgram, Sroloff, \& Rosenbaum (1988) juga menegaskan bahwa hal tesebut disebabkan oleh adanya kecenderungan individu berkepribadian tipe A yang suka mengerjakan sesuatu dengan cepat sehingga tugas-tugasnya dapat terselesaikan dengan segera tanpa perlu menundanya. Rasa kompetitif yang tinggi dan usaha yang keras (hard-driving) untuk mendapatkan suatu penghargaan juga memaksa individu berkepribadian tipe A untuk mengerjakan tugasnya lebih baik dan lebih cepat dari orang lain meski beberapa tugas tak disukainya.

Sebaliknya semakin rendah kecenderungan pola perilaku kepribadian tipe A atau yang disebut dengan pola perilaku kepribadian tipe B maka semakin tinggi prokastinasinya. Hal tersebut disebabkan pola perilaku kepribadian tipe B yang cenderung santai dalam hal waktu, tidak menyukai kesulitan serta tidak berorientasi pada penghargaan sehingga membuat individu tersebut menghindarkan diri pada tugas-tugas yang menyulitkannya atau tidak disukainya dan melakukan suatu tindakan penundaan. Dalam hal ini, studi yang dilakukan oleh Milgram, Sroloff, \& Rosenbaum (1988) mengindikasikan prokrastinasi tidak berkaitan dengan ciri individu kepribadian tipe A.

Hal tersebut juga diperkuat oleh studi yang dilakukan Watson (dalam Díaz-Moralez, Cohen, \& Ferrari, 2008) yang menjelaskan bahwa prokrastinasi memang berkaitan dengan ciri individu kepribadian tipe B. Namun lain halnya dengan Aristia (2010) yang meneliti 99 siswa SMA Regina Pacis Ursulin Solo dan didapatkan hasil bahwa tidak ada perbedaan tingkat prokrastinasi akademik ditinjau dari kepribadian tipe A dan tipe B.

Berdasarkan latar belakang masalah, hasil kajian sebelumnya serta kajian teori yang ada hiopotesis yang dibuktikan dalam penelitian ini adalah: Ada perbedaan yang tingkat prokrastinasi akademik dalam menyelesaikan skripi yang signifikan diantara mahasiswa bertipe kepribadian A dengan mahasiswa bertipe kepribadian B pada Fakultas Psikologi Universitas Kristen Satya Wacana Salatiga.

\section{Metode Penelitian}

Jenis penelitian ini adalah penelitian kuantitatif yang bersifat ex post facto.

Populasi penelitian ini adalah mahasiswa Fakultas Psikologi Universitas Kristen Satya Wacana (UKSW) yang sedang menjalani proses pengerjaan skripsi pada semester genap 2011/2012 yang berjumlah 159 orang.

Pengambilan sampel menggunakan teknik incidental sampling. Semua anggota populasi dijadikan sebagai anggota sampel. 
Pengumpulan data dalam penelitian ini menggunakan metode angket/kuisioner. Prokrastinasi akademik dalam menyelesaikan skripsi diukur menggunakan angket modifikasi Tuckman Procrastination Scale (TPS) sedangkan kepribadian tipe A dan B diukur dengan menggunakan modifikasi skala Bortner. Pada modifikasi TPS dibuat berdasarkan 3 aspek prokrastinasi yang dikemukakan oleh Tuckman (1990) yaitu: (1) Tendency to delay or put off doing things atau dikenal dengan istilah "time waster" yaitu pembuang waktu. (2) Tendency to have difficulty doing unpleasant things and when possible to avoid or circumvent the unpleasantness atau dikenal dengan istilah "task avoidance" yaitu kesulitan \& penghindaran dalam melakukan sesuatu yang tidak disukai. (3) Tendency to blame others for one's own plight atau dikenal dengan istilah "blaming others" yaitu mempersalahkan orang lain.

Skala pengukuran pola perilaku kepribadian tipe A \& tipe B disusun berdasarkan skala Bortner (dalam Edwards, Baglioni, \& Cooper, 1990) yang telah dimodifikasi ke dalam konteks perkuliahan. Modifikasi skala ini terdiri dari 14 pasang item pernyataan. Sistem skoring modifikasi skala Bortner adalah dengan memberikan skor pada setiap interval dalam jangkauan kontinum yang terdiri dari 5 interval. Pada setiap pasangan, ciri kepribadian tipe A terletak di kolom sebelah kiri sedangkan ciri kepribadian tipe B terletak di kolom yang berlawanan yaitu di kolom sebelah kanan.

\section{HASIL PENELITIAN DAN PEMBAHASAN}

Penyebaran angket penelitian dilaksanakan dari tanggal 19 Maret 2012 sampai dengan tanggal 22 April 2012. Terdapat 5 subjek mengisi angket melalui attachment dalam jejaring sosial Facebook dan hanya 3 yang kembali sedangkan 2 yang lainnya tidak kembali. Selanjutnya terdapat 116 orang saja yang mengembalikan dan mengisi angket

Berdasarkan uji validitas dan reliabilitas modifikasi Skala Bortner item-item mempunyai koefisien korelasi item total yang bergerak dari $r=0.207$ sampai dengan $r=0.61$ yang semuanya valid karena $r>0,20$. Adapun reliabilitasnya sebesar 0,759 yang berarti juga bahwa instrumen tersebut adalah reliabel dengan kategori dapat diterima. Selanjutnya uji validitas modifikasi TPS dari 35 item diperoleh 30 item valid dan 5 item tidak valid. Adapun koefisien reliabilitasnya sebesar 0,809 dengan kategori baik.

Untuk memasukkan subyek kedalam salah satu tipe kepribadian digunakan interval dari hasil pengukuran tipe kepribadian yang didasarkan pada 14 item yang ada. Rentang skor dari $14-$ 36,4 masuk dalam tipe B dan skor 47,6 - 70 masuk dalam tipe A. Untuk interval 36,4-47,60 tidak dimasukkan dalam salah satu tipe yang ada karena orang yang berada pada interval itu tidak secara tegas masuk dalam tipe A atau tipe B. Berdasarkan pada kategori atau interval tersebut diperoleh 28 subjek masuk ke dalam kategori kepribadian tipe A dan 35 subyek masuk dalam kategori kepribadian tipe B (lihat gambar).

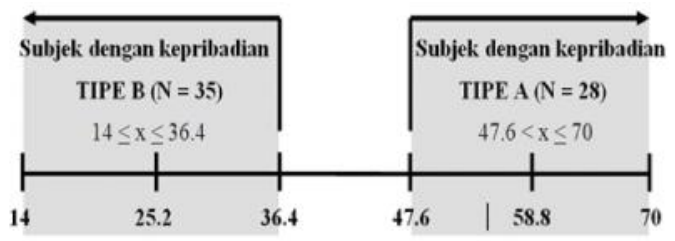

Subjek dengan skor $36.4<\mathrm{x} \leq 47.6$ (kategori tipe A sedang dan tipe B sedang) tidak diikutsertakan dalam analisis selanjutnya. 
Hasil analisis data dengan menggunakan bantuan program SPSS for Windows version 16.00, dihasilkan nilai t-hitung adalah sebesar -4.571 dan sig (1-tailed) $\mathrm{p}=0.000<0.05$ yang artinya hipotesis nihil ditolak dan hipotesis penelitian diterima. Nilai $p<0,05$ menunjukkan bahwa perbedaan tersebut signifikan. Dengan demikian hipotesis yang diajukan diterima yaitu ada perbedaan signifikan tingkat prokrastinasi akademik dalam menyelesaikan skripsi pada mahasiswa Fakultas Psikologi UKSW ditinjau dari kepribadian tipe A dan tipe B. Hasil yang diperoleh adalah kelompok mahasiswa dengan kepribadian tipe A memperoleh mean dari skor prokrastinasi sebesar 65.9643 yang berada pada kategori rendah. Sedangkan kelompok mahasiswa dengan kepribadian tipe B memperoleh mean dari skor prokrastinasi sebesar 82.3429 yang berada pada kategori sedang. Dalam hal ini, disimpulkan bahwa tingkat prokrastinasi mahasiswa dengan kepribadian tipe B lebih tinggi dibandingkan mahasiswa dengan kepribadian tipe A.

Hasil penelitian ini mendukung penelitian yang dilakukan oleh Milgram, Sroloff, \& Rosenbaum (1988) sebelumnya bahwa individu dengan pola perilaku kepribadian tipe A yang tinggi maka semakin rendah prokrastinasinya, sebaliknya semakin individu mempunyai pola perilaku kepribadian tipe A yang rendah, dalam hal ini individu tersebut mempunyai pola perilaku kepribadian tipe B maka semakin tinggi prokrastinasinya. Selain itu, penelitian ini juga mendukung pendapat Watson (dalam Diaz-Moralez, Cohen, \& Ferrari, 2008) yang mengemukakan bahwa prokrastinasi memang cenderung ditunjukkan oleh individu dengan kepribadian tipe B. Tetapi hasil penelitian tidak mendukung penelitian yang dilakukan oleh Aristia (2010) yang menyatakan bahwa tidak ada perbedaan tingkat prokrastinasi antara individu dengan kepribadian tipe A dan tipe B.

Adanya perbedaan ini dibenarkan oleh Milgram, Sroloff \& Rosenbaum (1988) karena sifat dari individu berkepribadian tipe A yang cenderung suka mengerjakan beberapa pekerjaan sekaligus dalam satu waktu yang sama dan bergerak cepat sehingga dapat terselesaikan dengan segera tanpa perlu menundanya. Dalam kajian ini dapat dilihat pada tingginya persentase dukungan melalui jawaban sangat setuju mahasiswa bertipe kpribadian A pada beberapa item yang berkaitan dengan mengerjakan beberapa tugas kuliah dalam waktu bersamaan" (75\%) serta item nomor 10 yang menyatakan "bergerak cepat dalam mengerjakan hal-hal yang berkaitan dengan perkuliahan" (57,15\%). saya memenuhi janji dengan pembimbing atau subjek skripsi tepat waktu" (78.56\%), serta "apapun yang terjadi, saya akan tetap mengerjakan skripsi sesuai jadwal/rencana yang saya buat" (88.72\% ), "saya adalah pembuang waktu yang tak tersembuhkan dalam membuat skripsi" (64,28\% tidak mendukung).

Sebaliknya Milgram, Sroloff, dan Rosenbaum (1988) juga mengutarakan bahwa individu dengan kepribadian tipe B cenderung santai dalam hal waktu, mengerjakan tugasnya satu per satu, tidak menyukai kesulitan serta tidak berorientasi pada penghargaan sehingga membuat individu tersebut cenderung menghindar dari tugas-tugas yang menyulitkannya atau tidak disukainya. Dalam hal ini, mahasiswa Fakultas Psikologi UKSW yang sedang menjalankan proses pengerjaan skripsi pada semester genap 2011/2012 dengan kepribadian tipe B cenderung santai dalam mengerjakan skripsinya yang merupakan tugas perkuliahan meskipun dikejar oleh waktu atau jadwal. Hal tersebut dapat dilihat dari beberapa jawaban mahasiswa pada beberapa item yang sifatnya tidak mendukung. Misalnya: "Santai mengerjakan tugas meski diburu oleh batas waktu yang sudah dekat" (77,16\% setuju atau sangat setuju), mengerjakan kuliah dengan santai yang penting selesai" (68,58\% setuju atau sangat setuju), "saya mengerjakan skripsi di saat-saat terakhir ketika harus diserahkan kepada pembimbing" (54,28\% setuju atau sangat setuju). 


\section{KESIMPULAN}

\section{Kesimpulan Penelitian}

1. Ada perbedaan yang signifikan antara tingkat prokrastinasi akademik dalam menyelesaikan skripsi ditinjau dari kepribadian tipe A dan tipe B. Mahasiswa dengan kepribadian tipe A mempunyai tingkat prokrastinasinya lebih rendah dibandingkan dengan kelompok mahasiswa dengan kepribadian tipe B.

2. Dalam konteks penelitian pada mahasiswa fakultas Psikologi UKSW semester genap 20112012 tingkat prokrastinasi mahasiswa dengan kepribadian tipe A berada pada kategori rendah dengan mean 65.9643 sedangkan pada mahasiswa dengan kepribadian tipe B tingkat prokrastinasi-nya berada pada kategori sedang dengan mean 82.3429.

\section{Saran}

Bagi para mahasiswa agar dapat meminimalkan terjadinya prokrastinasi akademik dalam menyelesaikan skripsi dengan cara mengelola waktu misalnya dengan membuat daftar harian tentang kegiatan-kegiatan yang harus diselesaikan, membuat jadwal mengerjakan skripsi dengan teratur dan menepatinya, mengetahui siklus bioritmik diri sendiri dalam mengerjakan skripsi yang menuntut tenaga dan pikiran pada saat bioritmik sedang tinggi.

Dosen pembimbing atau wali studi perlu mengenal tipe kepribadian mahasiswa terutama bagi mahasiswa yang berkepribadian tipe B agar dapat merancang dan melakukan tindakan preventif dan kuratif guna menghindarkan mahasiswa dari prokrastinasi akademik dalam menyelesaikan skripsi maupun tugas-tugas kuliah lainnya.

Bagi Fakultas kiranya dapat melakukan kegiatan-kegiatan pelatihan yang bertujuan untuk mengurangi prokrastinasi akademik khususnya bagi mahasiswa yang bertipe kepribadian B supaya lama studi mahasiswa sesuai dengan jadwal yang telah ditetapkan.

Mahasiswa perlu berpikir bahwa prokastinasi akademik akan banyak membawa kerugian, dan untuk itu supaya mahasiswa memikirkan kembali apa yang kira-kira menjadi faktor utama sehingga terjadi prokrastinasi akademik tersebut. Jika telah diketahui penyebab utamanya, mahasiswa tidak perlu takut untuk konsultasi dengan wali atau pembimbing untuk mencari jalan keluarnya sehingga dapat menyelesaikan skripsi sesuai dengan jadwal yang telah ditetapkan.

\section{DAFTAR PUSTAKA}

Aristia, A. 2010. Perbedaan prokrastinasi akademik di antara kepribadian tipe A dan tipe B. Skripsi (Tidak Diterbitkan). Fakultas Psikologi Universitas Kristen Satya Wacana.

Burka, J. B., \& Yuen, L. M. 2008. Procrastinatiom: why you do it, what to do with it now. New York: Da Capo Press A Member of The Perseus Book Groups.

Catrunada, L., \& Puspitawati, I. 2008. Perbedaan kecenderungan prokrastinasi tugas skripsi berdasarkan tipe kepribadian introvert dan ekstrovert. Skripsi (Tidak Diterbitkan). Fakultas Psikologi Universitas Gunadarma.

Chu, A. H. C., \& Choi, J. N. 2005. Rethinking procrastination: Positive effects of "active" procrastination behavior on attitudes and performance. Journal of Social Psychology, 145(3), 245-264. 
Diaz-Moralez, J. F., Cohen, J. R., \& Ferrari, J. R. 2008. An integrated view of personality styles related to avoidant procrastination. Journal of Personality And Individual Differences, 45, 554-558.

Edwards, J. R., Baglioni, A. J., \& Cooper, C. L. 1990. The psychometric properties of the Bortner Type A Scale. British Journal of Psychology, 81, 315-333.

Ferrari, J. R., \& Tice, D. M. 2000. Procrastination as a self-handicap for men and women: A taskavoidance strategy in a laboratory setting. Journal of Research in Personality, 34, 73-83.

Ferrari, J. R., Johnson, J., \& McCown, W. 1995. Procrastination and task avoidance: Theory, research and treatment. New York: Plenum Press.

Friedman, M., \& Rosenman, R. H. 1974. Type A Behavior and Your Heart. New York: Knopf.

Gunawinata, V. A. R., Nanik, \& Lasmono, H. K. 2008. Perfeksionisme, prokrastinasi akademik, dan penyelesaian skripsi mahasiswa. Anima - Indonesian Psychology Journal, 22(3), 256-276.

Milgram, N. A., Sroloff, B., \& Rosenbaum, M. 1988. The procrastination of everyday life. Journal of Research in Personality, 22, 197-212.

Sobur, A. 2003. Psikologi umum. Bandung: CV. Pustaka Setia.

Solomon, L. J., \& Rothblum, E. D. 1984. Academic procrastination: Frequency and cognitive behavioral correlates. Journal of Counseling Psychology, 31(4), 503-509.

Tuckman, B. W. 1990. Measuring procrastination atitudinally and behaviorally. Paper Presented at the Annual Meeting of The American Educational Research Association. 
Satya Widya, Vol. 28, No.2. Desember 2012 